\title{
Successful rapid weight reduction and the use of liraglutide for morbid obesity in adolescent Prader-Willi syndrome
}

\author{
Yoo-Mi Kim, MD, PhD', \\ Yeoun Joo Lee, MD, PhD', \\ Soo Yeon Kim, MD, PhD, \\ Chong Kun Cheon, MD, PhD², \\ Han Hyuk Lim, MD, PhD ${ }^{1}$
}

'Department of Pediatrics, Chungnam National University Hospital, Chungnam National College of Medicine, Daejeon, Korea

${ }^{2}$ Department of Pediatrics, Pusan National University Children's Hospital, Pusan National College of Medicine, Yangsan, Korea

${ }^{3}$ Department of Rehabilitation, Pusan National University Children's Hospital, Pusan National College of Medicine, Yangsan, Korea
Received: 24 May, 2019

Revised: 4 August, 2019

Accepted: 9 August, 2019

\author{
Address for correspondence: \\ Yoo-Mi Kim, MD, PhD \\ Department of Pediatrics, College \\ of Medicine, Chungnam National \\ University Hospital, 282 Munhwa-ro, \\ Jung-gu, Daejeon 35015, Korea \\ Tel: $+82-42-280-7288$ \\ Fax: +82-42-255-3158 \\ E-mail:ym4805@gmail.com \\ https://orcid.org/0000-0002-8440- \\ 5069
}

Prader-Willi syndrome (PWS), an imprinting disorder, results from the loss of expression of a paternal gene on chromosome 15q11-q13. Progressive obesity and its associated complications lead to increased morbidity and early death in PWS patients. The management techniques available for morbid obesity in adolescents and adults with PWS are limited. Herein, we report successful weight reduction in an adolescent PWS case showing morbid obesity and respiratory failure. An 18-year-old girl with PWS presented with diffuse cellulitis and dyspnea due to severe obesity. Her body weight had increased from 146 to $161 \mathrm{~kg}$ despite dietary restriction to 800 $\mathrm{kcal} /$ day, and a mechanical ventilator was required for dyspnea. During mechanical ventilation, the patient was managed using diuretics and by restricting fluid intake; her daily calorie intake was reduced to $200 \mathrm{kcal}$. This aggressive calorie and water restriction continued for 3 weeks and reduced her body weight to $118.6 \mathrm{~kg}$. After transfer to the general ward, the patient was provided with growth hormone therapy and intensive aquatic rehabilitation and was administered liraglutide; as a result, her weight further decreased to $104 \mathrm{~kg}$ (body mass index [BMI], $50.8 \mathrm{~kg} / \mathrm{m}^{2}$ ), and she was discharged. Following discharge, she maintained her BMI and adapted to $1,000 \mathrm{kcal} /$ day for 1 year. Aggressive water and calorie restriction were observed as an effective method for rapid weight reduction in PWS patients, and liraglutide appeared useful in maintaining weight reduction in adolescent and adult PWS.

Keywords: Liraglutide, Prader-Willi syndrome, Adolescent, Obesity, Morbid

\section{Introduction}

Prader-Willi syndrome (PWS, OMIM \#176270) is an imprinting disorder resulting from a deletion in paternally derived alleles located on $15 \mathrm{q} 11-\mathrm{q} 13 .{ }^{1)}$ Its prevalence is 1 in 10,000 to 30,000 and is not sex-linked. ${ }^{2)}$ Hypothalamic dysfunction from paternally imprinted gene deletions is the main pathogenesis of PWS and is characterized by short stature, infantile hypotonia, hypothalamic hypogonadism, excessive appetite, and progressive obesity. ${ }^{1,2)}$ Although PWS patients treated with recombinant human growth hormone therapy (rhGH; approved by the U.S. Food and Drug Administration since 2000) show improved final height, resting metabolic rate, and body fat composition and a lower body mass index (BMI), problems related to appetite and progressive obesity in adolescent and adult patients remain unsolved. ${ }^{3)}$ Morbid obesity in PWS leads to increased risk of cardiopulmonary compromise, type 2 diabetes mellitus (DM), chronic leg edema, premature cardiovascular disease, and death. ${ }^{1,2)}$ Recently, several clinical trials have revealed the effects of reduced hypothalamic appetite on BMI reduction. ${ }^{4)}$ Herein, we report the effectiveness of a glucagon like peptide-1 (GLP-1) agonist, liraglutide, and 1-year multidisciplinary management of a Korean adolescent PWS patient with morbid obesity and respiratory failure. 


\section{Case report}

An 18-year-old girl presented with dyspnea and diffuse cellulitis in the abdomen and both legs. She had been born at 40 weeks by cesarean section with a birth weight of $1.9 \mathrm{~kg}$. Typical hypotonia and poor oral intake during infancy had been noted in the patient, which was followed by rapid weight gain and intellectual disability during childhood. The diagnosis of PWS was made at 14 years of age, and the paternal deletion was identified through methylation test and fluorescence in situ hybridization for 15q11-q13. Growth hormone (GH) therapy could not be applied due to the patient's advanced bone age (over 14 years) at that time. Her intelligence quotient was measured as 30 , and type $2 \mathrm{DM}$ and hypertension were diagnosed when she was 16 years old and were treated with metformin and a calcium channel blocker, respectively. The patient's parents tried to limit her food intake, and her daily calorie intake was approximately $1,600 \mathrm{kcal}$. At the time of the visit, the patient's height, weight, and BMI were $143 \mathrm{~cm} \mathrm{(-3.8} \mathrm{standard} \mathrm{deviation}$ score [SDS]), $145 \mathrm{~kg}(4.5 \mathrm{SDS})$, and $71 \mathrm{~kg} / \mathrm{m}^{2}$, respectively (Table 1). Her vital signs were 190/100 mmHg, 115 beats/min, 24 breaths $/ \mathrm{min}$, and $36^{\circ} \mathrm{C}$ body temperature. She was unable to walk or sit unaided due to joint pain and massive cellulitis in the abdomen and legs (Fig. 1A, B). Before the hospital visit, her body weight had increased rapidly by $20 \mathrm{~kg}$ due to reduced physical activity for the previous 2 weeks. Ampicillin/sulbactam was administered for cellulitis, and her daily calorie intake was restricted to $800 \mathrm{kcal} /$ day for 1 week; however, her body weight increased to $164 \mathrm{~kg}$ (4.7 SDS), and her dyspnea was aggravated. The patient was put on mechanical ventilation for 20 days, and her calorie intake was restricted to $200 \mathrm{kcal} /$ day. Furosemide (40 mg every 8 hours) and fluid restriction (1000 $\mathrm{mL} /$ day, $5 \%$ dextrose with $600-\mathrm{mL}$ electrolytes and $400-\mathrm{mL}$ free water) were used to induce a massive bodyweight reduction. After loss of $26 \mathrm{~kg}$, extubation was successfully performed. The patient's electrolytes had been closely monitored and balanced (Na, 135-142 mEq/L; K, 3.3-4.0 mEq/L) during the weight reduction process. A pituitary function test was performed due to primary amenorrhea, which revealed hypopituitarism, including $\mathrm{GH}$ and gonadotropin deficiencies. Low dosages of GH (1.33 IU/day) and estrogen $(0.125 \mathrm{mg} /$ day $)$ were therefore administered. In addition to the high dosage of metformin (1,500 mg/day), a GLP-1 receptor agonist (Liraglutide, Victoza, Novo Nordisk, Denmark) was added for appetite reduction. The serum glycosylated hemoglobin (HbAlc) level was observed as 7.3\%. The GLP-1 agonist dosage was initiated at $0.6 \mathrm{mg} /$ day and increased to $1.2 \mathrm{mg} /$ day without an adverse event. In addition, physical therapy, including aerobic exercise and pulmonary rehabilitation, was implemented for 60 minutes per day, 5 days/ wk. At the time of discharge ( 3 months after admission), the patient was able to walk independently, and her weight and BMI had decreased to $104 \mathrm{~kg}$ and $50.8 \mathrm{~kg} / \mathrm{m}^{2}$, respectively (Table 1). The $\mathrm{HbAlc}$ level was reduced from $7.3 \%$ to $4.8 \%$ during these 3 months. After 1 year, the patient's BMI was maintained at 48.5 $\mathrm{kg} / \mathrm{m}^{2}$, and she was satisfied on a diet of $1,000 \mathrm{kcal} /$ day diet comprised of carbohydrates (100 g), proteins ( $48 \mathrm{~g}$ ), and fat (42 g). In addition, regular mealtimes and expected food amounts were maintained. The patient had continued to exercise daily for 1 hour with familial support. After 1 year, a waist circumference reduction $(7 \mathrm{~cm})$, weight loss $(62.7 \mathrm{~kg})$, and BMI reduction $(31.7$ $\mathrm{kg} / \mathrm{m}^{2}$ ) were noted (Fig. 2).

\section{Discussion}

Excessive obesity in PWS is explained by several mechanisms, including low energy expenditure, lack of satiety, and high food intake. ${ }^{1,2)}$ Hyperphagia leads to acute gastric necrosis or even rupture. ${ }^{1,2)}$ A previous report demonstrated respiratory failure due to morbid obesity and the need for long-term mechanical ventilation in a patient with PWS and concluded that weight reduction was important for weaning off a mechanical ventilator. ${ }^{5)}$ In the present case, management of the patient by massive fluid and calorie restriction intended to lead to rapid BMI reduction aided in weaning off the mechanical ventilator in a faster amount of time than in previous reports. Fluid accumulation may play a role in rapid weight gain and

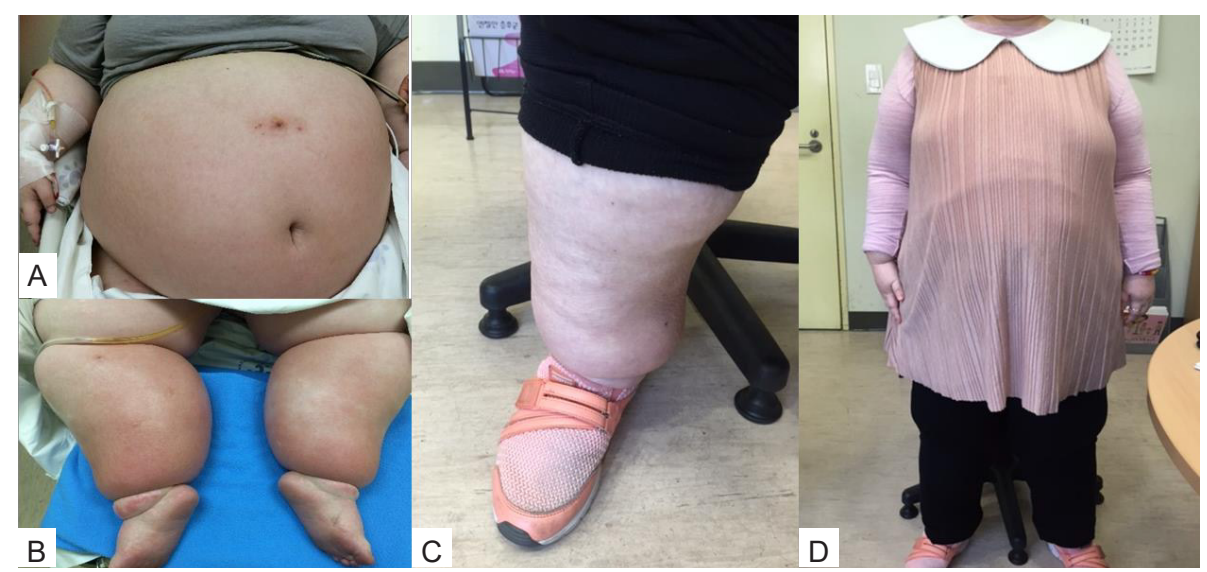

Fig. 1. Clinical photographs of the patient at her first visit $(A, B)$ and 1 year after discharge $(C, D)$. 
Table 1. Clinical course and BMI reduction in patient with Prader-Willi syndrome

\begin{tabular}{|c|c|c|c|c|c|c|}
\hline Variable & At admission & $\sim 2$ Weeks & 3-5 Weeks & 6 Weeks & 7-10 Weeks & 11-12 Weeks \\
\hline BMI $\left(\mathrm{kg} / \mathrm{m}^{2}\right)$ & 71 & 80.2 & $77.8 \rightarrow 66.1$ & 59.8 & $54.8 \rightarrow 52.6$ & $52.2 \rightarrow 50.8$ \\
\hline $\begin{array}{l}\text { Body weight } \\
\text { (kg) }\end{array}$ & 145 & 164 & $159 \rightarrow 135.2$ & 122.2 & $112.2 \rightarrow 107.6$ & $106.7 \rightarrow 104$ \\
\hline $\begin{array}{l}\text { Total volume } \\
(\mathrm{mL})\end{array}$ & 2,000 & $2,000 \rightarrow 1,600$ & 1,600 & 1,600 & 1,600 & 1,600 \\
\hline $\begin{array}{r}\text { Oral intake } \\
\text { (kcal/day) }\end{array}$ & $\begin{array}{c}1,600(S D) \rightarrow 1,000 \\
(S D)\end{array}$ & 800 (LD*) & $\begin{array}{c}200(\text { (LD }) \text {, water } 400^{*} \text { mL/day }\end{array}$ & $\begin{array}{l}200 \text { (LD), ORSt } \\
600 \rightarrow 800 \text { mL/day }\end{array}$ & $\begin{array}{c}600\left(\text { LD }^{*}\right), \mathrm{ORS}^{\dagger} 800 \\
\mathrm{~mL} / \text { day, water } \sim 200 \\
\mathrm{~mL} / \text { day }\end{array}$ & $800\left(\mathrm{LD}^{*}\right) \rightarrow \mathrm{SD}$ \\
\hline Medication & $\begin{array}{l}\text { Metformin } 1.5 \mathrm{~g} / \text { day, } \\
\text { insulin detemir (28 IU/ } \\
\text { day), amlodipine } 10 \\
\text { mg/day, hydralazine } \\
60 \mathrm{mg} / \text { day }\end{array}$ & $\begin{array}{l}5 \% \text { dextrose with } \mathrm{Na} / \\
\mathrm{K} \text { (DNK) } 600 \mathrm{~mL} / \text { day, } \\
\text { furosemide } 120 \mathrm{mg} / \\
\text { day, metfmormin } 1.5 \\
\text { g/day amlodipine } \\
20 \mathrm{mg} / \text { day, } \\
\text { losartan } 50 \mathrm{mg} / \\
\text { day, iron } 80 \mathrm{mg} / \text { day, } \\
\text { calcium carbonate/ } \\
\text { cholecalciferol }(1,250 \\
\text { mg/1,000 IU/day) }\end{array}$ & $\begin{array}{c}5 \% \text { DNK } \rightarrow \text { normal } \\
\text { saline (NS) } 600 \mathrm{~mL} \text {, } \\
\text { previous regimen+ } \\
\text { hydrochlorothiazide } \\
50 \mathrm{mg} / \text { day, } \\
\text { amlodipine } 40 \mathrm{mg} / \\
\text { day, losartan } 100 \mathrm{mg} / \\
\text { day }\end{array}$ & $\begin{array}{c}\text { NS } 600 \mathrm{~mL} \text {, previous } \\
\text { regimen+start } \\
\text { liraglutide }(0.6 \rightarrow 1.2 \\
\text { mg/day), growth } \\
\text { hormone. } 1.33 \mathrm{IU} / \text { day, } \\
\text { and estrrogen } 0.125 \\
\mathrm{mg} / \text { day }\end{array}$ & $\begin{array}{l}\text { Discontinuation of } \\
\text { diuretics, losartan }\end{array}$ & $\begin{array}{l}\text { Continue previous } \\
\text { regimen (metformin, } \\
\text { insulin detemir, } \\
\text { liraglutide, growth } \\
\text { hormone, estrogen, } \\
\text { amlodipine, } \\
\text { iron, calcium/ } \\
\text { cholecalciferol) }\end{array}$ \\
\hline Event & $\begin{array}{c}\text { Dyspnea, cellulitis on } \\
\text { abdomen \& leg, high } \\
\text { flow nasal cannula } 02 \\
\text { supply }\end{array}$ & $\begin{array}{c}\text { Start ICU care } \\
\text { and mechanical } \\
\text { ventilation (PCV) }\end{array}$ & $\begin{array}{c}\text { Mechanical } \\
\text { ventilation } \\
\text { (SIMV-CPAP } \\
\text { mode) } \rightarrow \text { extubation }\end{array}$ & $\begin{array}{l}\text { High flow nasal } \\
\text { cannula } \mathrm{O}_{2} \text { supply }\end{array}$ & $\begin{array}{l}\text { Transfer to general } \\
\text { ward, } \mathrm{O}_{2} \text { off, start } \\
\text { aquatic rehabilitation } \\
\text { ( } 1 \mathrm{hr} / \text { day, } 5 \text { day/wk) }\end{array}$ & $\begin{array}{l}\text { Transfer to } \\
\text { rehabilitation } \\
\text { center (continue } \\
\text { rehabilitation) } \\
\rightarrow \text { discharge }\end{array}$ \\
\hline $\begin{array}{l}\mathrm{Na} / \mathrm{K} \\
(\mathrm{mEq} / \mathrm{L})\end{array}$ & $139 / 4.2$ & $138 / 5.1$ & $135 / 4.4-142 / 4.4$ & $129 / 4.5$ & $132 / 4.6-138 / 4.6$ & $142 / 4.7$ \\
\hline $\begin{array}{l}\text { Blood } \\
\text { pressure } \\
(\mathrm{mmHg})\end{array}$ & $190 / 100 \rightarrow 150 / 90$ & $130 / 100$ & $162 / 87$ & $113 / 43$ & $120 / 70$ & $120 / 70$ \\
\hline
\end{tabular}

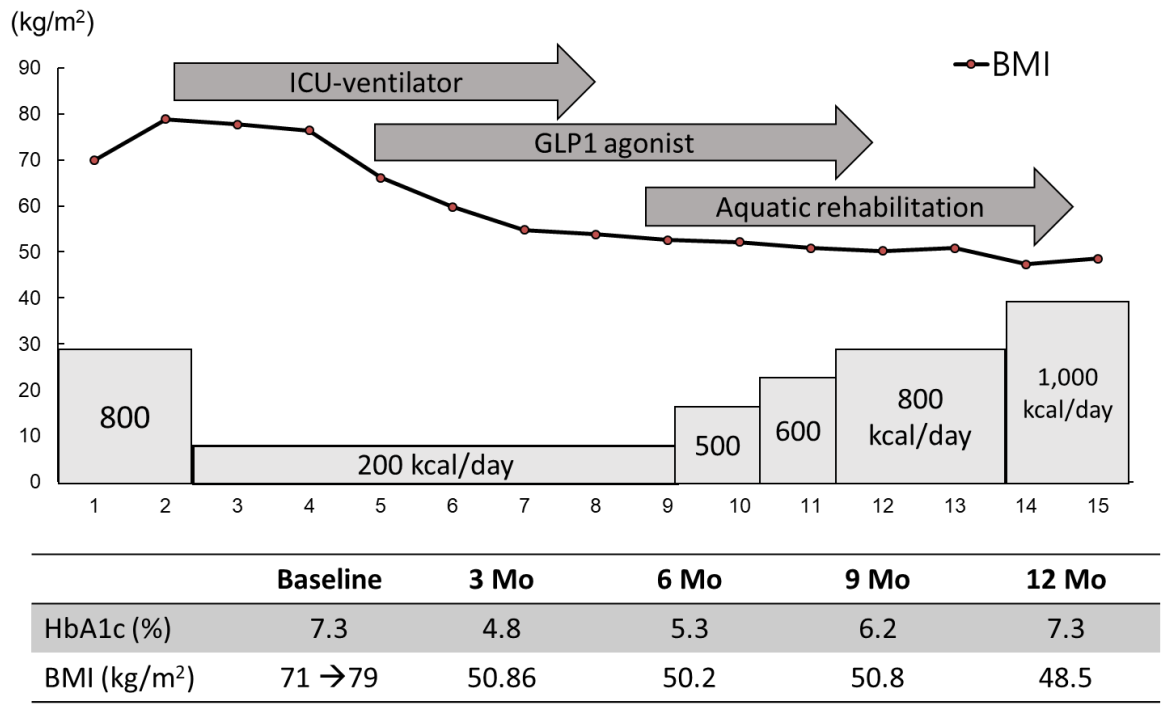

Fig. 2. The short-term and long-term effects on body mass index (BMI) reduction due to food restriction, intensive aquatic rehabilitation, and medication in a patient with Prader-Willi syndrome. ICU, intensive care unit; $\mathrm{HbA} 1 \mathrm{C}$, glycosylated hemoglobin. 
dyspnea in morbid obesity. In severe obesity, lymphatic flow can be disturbed, and increased hydrostatic pressure leads to fluid leakage into the tissues.) Therefore, aggressive diuretic use and massive fluid restriction may be effective at reducing body weight for a short time, despite concerns of electrolyte imbalance and blood pressure drops during treatment. Controlling the patient's food intake during ventilator use was easy due to use of sedatives. However, intake control became complicated after the discontinuation of the sedatives. Liraglutide was administered for both blood glucose control and appetite reduction. GLP-1 receptor agonists, which include exenatide or liraglutide, have been reported to be effective at reducing appetite and improve blood glucose in some obese patients.")

A recent pilot study revealed that both PWS and obese patients ( $\mathrm{n}=8$ and 11 , respectively) who were administered a single $10-\mu \mathrm{g}$ exenatide injection or placebo in a single-blinded, crossover design showed increased satiety, lowered glucose level, and insulinotropic effects. ${ }^{8)}$ Following 1 year of exenatide use, a 19-year-old female PWS patient demonstrated marked reduction in body weight and food consumption, ${ }^{9)}$ and a 25-year-old female PWS patient showed decrease in BMI and ghrelin level compared to those seen in obese patients with diabetes. ${ }^{10)}$ Six PWS patients displayed improved BMI, HbAlc, and waist circumference after 24 months of exenatide or liraglutide treatment. ${ }^{11}$ However, 10 PWS patients showed no significant changes in BMI, weight $z$-score, and ghrelin when the effectiveness was measured after 6 months of exenatide use, even though improved $\mathrm{HbAlc}$ level and decreasing appetite scores were noted. ${ }^{12)}$

Acylated ghrelin is an orexigenic hormone, and ghrelin level in children and young adults with PWS is higher than those of sibling control and early onset morbid obesity groups. ${ }^{13)}$ Recently, unacylated ghrelin, which can inhibit acylated ghrelin, appeared effective in hyperphagia and has been investigated for treatment of adolescent and adult PWS patients. ${ }^{14)}$ Oxytocin (a potent anorexigenic hormone) and intranasal carbetocin (an oxytocin analogue) also have been introduced to improve hyperphagia and the behavioral symptoms of adolescent PWS patients. ${ }^{15)}$ Several medications have entered phase 2 or 3 of clinical trials for PWS patients (https://www.fpwr.org/ pws-clinical-trials), and this therapeutic approach of appetite modulation via the hypothalamus could provide promising results not only in PWS patients, but also for patients with other types of hypothalamic obesity.

In this study, we successfully treated a severely obese, adolescent PWS patient with multidisciplinary management and GLP-1 receptor agonist use. GLP-1 receptor agonists aid in appetite and weight reduction and could be an effective treatment for PWS. However, large cohort, controlled, and longterm trials in patients with PWS will be required to confirm the efficacy and safety of GLP-1 receptor agonists and analogues.

\section{Ethical statement}

The authors did not seek the approval of the Institutional
Review Board for this case report. However, informed consent was obtained from the patient and her parents regarding the reporting and publication of this case report. As the present case is not a clinical trial and no off-label drugs were used, ethical approval was not necessary.

\section{Conflict of interest}

No potential conflict of interest relevant to this article was reported.

\section{Acknowledgments}

We thank the patient and her family for participating in the study, and special thanks also goes to Seung Kook Sohn (MD), a pediatric intensive care unit specialist, who helped manage the patient.

\section{References}

1. Cassidy SB, Schwartz S, Miller JL, Driscoll DJ. Prader-Willi syndrome. Genet Med 2012;14:10-26.

2. Goldstone AP, Holland AJ, Hauffa BP, Hokken-Koelega AC, Tauber M; speakers contributors at the Second Expert Meeting of the Comprehensive Care of Patients with PWS. Recommendations for the diagnosis and management of Prader-Willi syndrome. J Clin Endocrinol Metab 2008;93:4183-97.

3. Deal CL, Tony M, Höybye C, Allen DB, Tauber M, Christiansen JS, et al. GrowthHormone Research Society workshop summary: consensus guidelines for recombinant human growth hormone therapy in Prader-Willi syndrome. J Clin Endocrinol Metab 2013;98:E1072-87.

4. Miller JL, Strong TV, Heinemann J. Medication trials for hyperphagia and food-related behaviors in Prader-Willi syndrome. Diseases 2015;3:78-85.

5. Sze L, Purtell L, Jenkins A, Loughnan G, Smith E, Herzog $\mathrm{H}$, et al. Effects of a single dose of exenatide on appetite, gut hormones, and glucose homeostasis in adults with PraderWilli syndrome. J Clin Endocrinol Metab 2011;96:E1314-9.

6. Nishikawa M, Mizutani T, Nakao T, Kamoda T, Takahashi S, Toyooka H. Respiratory failure due to morbid obesity in a patient with Prader-Willi syndrome: an experience of longterm mechanical ventilation. J Anesth 2006;20:300-3.

7. Yosipovitch G, DeVore A, Dawn A. Obesity and the skin: skin physiology and skin manifestations of obesity. J Am Acad Dermatol 2007;56:901-16.

8. Khera R, Murad MH, Chandar AK, Dulai PS, Wang Z, Prokop LJ, et al. Association of pharmacological treatments for obesity with weight loss and adverse events: a systematic review and meta-analysis. JAMA 2016;315:2424-34.

9. Seetho IW, Jones G, Thomson GA, Fernando DJ. Treating diabetes mellitus in Prader-Willi syndrome with exenatide. Diabetes Res Clin Pract 2011;92:e1-2. 
10. Senda M, Ogawa S, Nako K, Okamura M, Sakamoto T, Ito S. The glucagon-like peptide-1 analog liraglutide suppresses ghrelin and controls diabetes in a patient with Prader-Willi syndrome. Endocr J 2012;59:889-94.

11. Fintini D, Grugni G, Brufani C, Bocchini S, Cappa M, Crinò A. Use of GLP-1 receptor agonists in Prader-Willi syndrome: report of six cases. Diabetes Care 2014;37:e76-7.

12. Salehi P, Hsu I, Azen CG, Mittelman SD, Geffner ME, Jeandron D. Effects of exenatide on weight and appetite in overweight adolescents and young adults with Prader-Willi syndrome. Pediatr Obes 2017;12:221-8.
13. Kweh FA, Miller JL, Sulsona CR, Wasserfall C, Atkinson M, Shuster JJ, et al. Hyperghrelinemia in Prader-Willi syndrome begins in early infancy long before the onset of hyperphagia. Am J Med Genet A 2015;167A:69-79.

14. Allas S, Caixàs A, Poitou C, Coupaye M, Thuilleaux D, Lorenzini F, et al. AZP-531, an unacylated ghrelin analog, improves food-related behavior in patients with PraderWilli syndrome: a randomized placebo-controlled trial. PLoS One 2018;13:e0190849.

15. Dykens EM, Miller J, Angulo M, Roof E, Reidy M, Hatoum HT, et al. Intranasal carbetocin reduces hyperphagia in individuals with Prader-Willi syndrome. JCI Insight 2018;3. 